\title{
Phenotype of Striatofugal Medium Spiny Neurons in Parkinsonian and Dyskinetic Nonhuman Primates: A Call for a Reappraisal of the Functional Organization of the Basal Ganglia
}

\author{
Agnes Nadjar, ${ }^{1}$ Jonathan M. Brotchie, ${ }^{3,4}$ Celine Guigoni, ${ }^{1}$ Qin Li, ${ }^{5}$ Shao-Bo Zhou, ${ }^{3}$ Gui-Jie Wang, ${ }^{3}$ Paula Ravenscroft, ${ }^{3}$ \\ François Georges, ${ }^{2}$ Alan R. Crossman, ${ }^{3}$ and Erwan Bezard ${ }^{1}$ \\ ${ }^{1}$ Centre National de la Recherche Scientifique Unité Mixte de Recherche 5543 et ${ }^{2}$ Institut National de la Santé et de la Recherche Médicale AVENIR 01, \\ Université Victor Segalen-Bordeaux 2, 33076 Bordeaux, France, ${ }^{3}$ School of Biological Sciences, University of Manchester, Manchester M13 9PT, United \\ Kingdom, ${ }^{4}$ Toronto Western Research Institute, Toronto Western Hospital, Toronto, Ontario, Canada M5T 2S8, and ${ }^{5}$ Laboratory Animal Research Center, \\ China Agricultural University, Beijing 100101, China
}

The classic view of anatomofunctional organization of the basal ganglia is that striatopallidal neurons of the "indirect" pathway express $\mathrm{D}_{2}$ dopamine receptors and corelease enkephalin with GABA, whereas striatopallidal neurons of the "direct" pathway bear $\mathrm{D}_{1}$ dopamine receptors and corelease dynorphin and substance P with GABA. Although many studies have investigated the pathophysiology of the basal ganglia after dopamine denervation and subsequent chronic levodopa (L-dopa) treatment, none has ever considered the possibility of plastic changes leading to profound reorganization and/or biochemical phenotype modifications of medium spiny neurons. Therefore, we studied the phenotype of striatal neurons in four groups of nonhuman primates, including the following: normal, parkinsonian, parkinsonian chronically treated with L-dopa without exhibiting dyskinesia, and parkinsonian chronically treated with L-dopa exhibiting overt dyskinesia. To identify striatal cells projecting to external (indirect) or internal (direct) segments of the globus pallidus, the retrograde tracer cholera toxin subunit $\mathrm{B}(\mathrm{CTb})$ was injected stereotaxically into the terminal areas. Using immunohistochemistry techniques, brain sections were double labeled for CTb and dopamine receptors, opioid peptides, or the substance P receptor (NK1). We also used HPLC-RIA to assess opioid levels throughout structures of the basal ganglia. Our results suggest that medium spiny neurons retain their phenotype because no variations were observed in any experimental condition. Therefore, it appears unlikely that dyskinesia is related to a phenotype modification of the striatal neurons. However, this study supports the concept of axonal collateralization of striatofugal cells that project to both globus pallidus pars externa and globus pallidus pars interna. Striatofugal pathways are not as segregated in the primate as previously considered.

Key words: globus pallidus; striatum; cholera toxin; dopamine receptor; dynorphin; enkephalin; immunohistochemistry; HPLC-RIA

\section{Introduction}

Many studies have investigated the pathophysiology of the basal ganglia after dopamine denervation [i.e., in a Parkinson's disease (PD)-like state] and subsequent chronic levodopa (L-dopa) treatment (i.e., in an L-dopa-induced dyskinesia-like state). However, none has ever considered the possibility of plastic changes leading to phenotype reorganization of efferent striatal medium spiny neurons (MSNs) connecting the striatum to the basal ganglia

Received June 20, 2006; revised July 12, 2006; accepted July 15, 2006.

This work was supported by grants from the Michael J. Fox Foundation for Parkinson's Research (E.B. and A.R.C.), the Medical Research Council (J.M.B. and A.R.C.), and the United Kingdom Parkinson's Disease Society (J.M.B. and A.R.C.). A.N. is a postdoctoral fellow funded through the grant from the Michael J. Fox Foundation for Parkinson's Research. The Université Victor Segalen-Bordeaux 2, the Centre National de la Recherche Scientifique (CNRS), and the Institut Federatif de Neurosciences (Institut National de la Santé et de la Recherche Médicale 8; CNRS 13) provided the infrastructural support. We thank Prof. G. Tramu and Dr. P. Ciofi for their expert help with opioid peptide immunohistochemistry and Drs. A. Parent and D. J. Surmeier for their critical reading of this manuscript.

Correspondence should be addressed to Dr. Erwan Bezard, Centre National de la Recherche Scientifique Unité Mixte de Recherche 5543, Université Victor Segalen-Bordeaux 2, 146 rue Léo Saignat, 33076 Bordeaux Cedex France. E-mail: erwan.bezard@umr5543.u-bordeaux2.fr.

D01:10.1523/JNEUROSCI.2582-06.2006

Copyright $\odot 2006$ Society for Neuroscience $\quad$ 0270-6474/06/268653-09\$15.00/0 output nuclei through the so-called "direct" and "indirect" pathways (Alexander and Crutcher, 1990). The current dogma states that the direct pathway, which comprises a set of neurons that project directly to the internal segment of the globus pallidus (GPi) or the substantia nigra pars reticulata $(\mathrm{SNr})$, expresses the $D_{1}$ dopamine receptor $\left(D_{1} R\right)$ and coreleases dynorphin and substance $\mathrm{P}$ with $\mathrm{GABA}$, whereas the indirect pathway, directed at the external pallidal segment (GPe), is formed by striatal neurons that bear the $\mathrm{D}_{2}$ dopamine receptor $\left(\mathrm{D}_{2} \mathrm{R}\right)$ and coreleases enkephalin with GABA. Such a simple view is, however, regularly challenged because qualitative anatomical studies clearly show that single striatofugal axons arborize in both pallidal segments in primates (Parent et al., 1995; Levesque and Parent, 2005).

Our understanding of basal ganglia physiology and pathophysiology is primarily built on our knowledge of the relative influence of the different pathways and on the putative changes affecting both their importance and/or phenotype in pathological situations such as PD and L-dopa-induced dyskinesia. StriatoGPi and striato-GPe neurons are similar in number and are indistinguishable in size, shape, and basic physiological properties 
(Parent and Hazrati, 1995), making it impossible with conventional approaches to distinguish between them in PD models. Therefore, the retrograde tracer cholera toxin subunit $\mathrm{B}(\mathrm{CTb})$ was injected stereotaxically into the terminal areas to identify striatal cells projecting to GPe or GPi in four experimental groups of nonhuman primates (NHPs), including the following: (1) normal, (2) parkinsonian, (3) parkinsonian chronically treated with L-dopa without exhibiting dyskinesia, and (4) parkinsonian chronically treated with L-dopa exhibiting overt dyskinesia. To evaluate phenotype changes of striatal neurons, brain sections were double labeled by immunohistochemistry for CTb and dopamine receptors (DARs; D1R, D2R) or opioid peptides [methionine (met)-enkephalin, dynorphin A, substance $\mathrm{P}$ receptor].

\section{Materials and Methods}

Animals. Sixteen female cynomolgus monkeys (Macaca fascicularis; Xierxin, Beijing, Peoples Republic of China) were used for the CTb experiments, and six female rhesus monkeys (Macaca mulatta; Fourth Military Medical University, Xi'an, Peoples Republic of China) were used for peptide analysis. Animals, weighing 3-6 kg (mean weight, $3.07 \pm 0.2 \mathrm{~kg}$; mean age, $4 \pm 0.9$ years), were housed in individual primate cages $(1.1 \mathrm{~m}$ high $\times 0.9 \mathrm{~m}$ deep $\times 0.8 \mathrm{~m}$ wide) under controlled conditions of humidity $(50 \pm 5 \%)$, temperature $\left(24 \pm 1{ }^{\circ} \mathrm{C}\right)$, and light ( $12 \mathrm{~h} \mathrm{light} /$ dark cycle, lights on at 8:00 A.M.). Food and water were available ad libitum, and veterinarians skilled in the healthcare and maintenance of NHPs supervised animal care. Experiments were performed in accordance with the European Communities Council Directive of November 24, 1986 (86/ 609/EEC), for care of laboratory animals. All efforts were made to minimize animal suffering and to use only the minimum number of animals necessary to produce reliable scientific data.

Experimental protocol. For the CTb experiment, 12 animals were intoxicated with 1-methyl-4-phenyl 1,2,3,6-tetrahydropyridine (MPTP) hydrochloride according to previously published methods (Bezard et al., 2001, 2003), and 4 animals remained untreated to form the normal (control) group. Once a bilateral parkinsonian syndrome had stabilized (i.e., unchanged disability score over at least 8 weeks; parkinsonian score range, $8-11$ ), four animals were maintained without exposure to L-dopa (MPTP group) and eight were treated twice daily with L-dopa (Modopar; F. Hoffmann-La Roche, Basel, Switzerland; L-dopa/carbidopa, ratio 4:1; $50-55 \mathrm{mg}$ ) for $6-8$ months at a titrated dose designed to produce a full reversal of parkinsonian symptoms (Bezard et al., 2003; Aubert et al., 2005). Four animals developed severe and reproducible dyskinesias 90 min after L-dopa administration, presenting choreic-athetoid (characterized by constant writhing and jerking motions), dystonic, and sometimes ballistic (large-amplitude flinging, flailing movements) movements (MPTP-treated, dyskinetic animal group; dyskinetic score $=3$ ), whereas four did not (MPTP-treated, non-dyskinetic animal group; dyskinetic score $=0$ ). The clinical assessments and the characterization of both the extent and pattern of nigrostriatal denervation were determined as published previously (Bezard et al., 2001; Aubert et al., 2005; Guigoni et al., 2005). Both the extent and pattern of nigrostriatal denervation are likely to play a role in the genesis of L-dopa-induced dyskinesia (Guigoni et al., 2005). The number of tyrosine hydroxylase-immunopositive neurons in the substantia nigra pars compacta, the striatal dopamine transporter, and tyrosine hydroxylase immunostaining were similar among the three MPTP-treated groups as shown previously (Guigoni et al., 2005). Moreover, the patterns of the lesion assessed by a detailed analysis of the tyrosine hydroxylase- and dopamine transporter-immunopositive striatal fibers were fully comparable in all functional striatal quadrants and at all rostrocaudal striatal levels considered, as shown previously (Guigoni et al., 2005).

For the peptide analysis, six normal animals were killed by a sodium pentobarbital overdose $(150 \mathrm{mg} / \mathrm{kg}$, i.v. $)$. Brains were removed rapidly and divided into the two hemispheres along the midline. Dissection was performed on ice with the brain immersed in cold saline $(0.9 \%)$. The striatum (combining caudate nucleus, putamen, and nucleus accumbens, across the rostrocaudal extent of the structure), GPe, GPi, subtha- lamic nucleus, substantia nigra (combining, when present, both the pars reticulata and compacta), thalamus, cerebellum, and cerebral cortex were dissected from each hemisphere, frozen at $-45^{\circ} \mathrm{C}$ in isopentane, and stored at $-80^{\circ} \mathrm{C}$. Striatal, GPe, and GPi tissues from the left hemisphere were subsequently subjected to peptide analysis, the data from which are reported here.

Tract tracing method. CTb (List Biological Laboratories, Campbell, CA) was prepared for injection as described previously (Georges and Aston-Jones, 2002). In brief, $1 \mathrm{mg}$ of lyophilized CTb was reconstituted with $1 \mathrm{ml}$ of $0.1 \mathrm{M}$ phosphate buffer (PB), $\mathrm{pH}$ 6.0. Animals were initially anesthetized with ketamine $\mathrm{HCl}(10 \mathrm{mg} / \mathrm{kg}$, i.m.), intubated, and placed in a stereotaxic apparatus (David Kopf Instruments, Tujunga, CA). Anesthesia was maintained with isoflurane delivered through a volumeregulated respirator. A scalp incision was made, a hole was drilled in the skull overlaying the pallidum, and the dura was reflected. Micropipettes (8-10 $\mu \mathrm{m}$ tip diameter) were backfilled with the $1 \%$ solution of $\mathrm{CTb}$ in $0.1 \mathrm{M} \mathrm{PB}, \mathrm{pH} 6.0$, and lowered stereotaxically into the GPi (15 mm anterior to ear bars; $7.0 \mathrm{~mm}$ lateral and $13.0 \mathrm{~mm}$ ventral to skull surface) (Martin and Bowden, 1996) in one hemisphere and into the GPe (16 mm anterior to ear bars; $9 \mathrm{~mm}$ lateral and $14 \mathrm{~mm}$ ventral to skull surface) (Martin and Bowden, 1996) in the other hemisphere of each animal. We injected $100 \mathrm{nl}$ of CTb by air pressure with a Picospitzer (General Valve Corporation, Fairfield, NJ). After the injection, the pipette was left in place for $15 \mathrm{~min}$ to prevent leakage of the tracer along the pipette track.

After recovery from anesthesia, animals resumed their drug treatment as per their original group for $15 \mathrm{~d}$. After those $15 \mathrm{~d}$, the animals were deeply anesthetized with sodium chloral hydrate $(150 \mathrm{mg} / \mathrm{kg}) 1 \mathrm{~h}$ after the last vehicle or L-dopa dose, and animals were perfused transcardially with a mixture of $2 \%$ paraformaldehyde and $0.2 \%$ glutaraldehyde in $\mathrm{PB}$ (0.1 м) (Bolam, 1992). Brains were removed, bisected along the midline, stored in $2 \%$ paraformaldehyde overnight, and cut into $60 \mu \mathrm{m}$ frontal sections with a Vibratome (VT1000S;Leica, Wetzlar, Germany). Sections were collected in PBS, cryoprotected in PBS with 25\% saccharose, freezethawed in isopentane, and stored in PBS with $0.03 \%$ sodium azide until processed for immunohistochemistry.

Antibodies, origin, and dilution. Goat anti-CTb antibody (List Biological Laboratories) was diluted at 1:20,000 for single-labeling (Georges and Aston-Jones, 2002) and at 1:5000 for double-labeling immunohistochemistry. $\mathrm{D}_{1} \mathrm{R}$ was detected by immunohistochemistry using a monoclonal antibody raised in rats against a 97 aa sequence corresponding to the $\mathrm{C}$ terminus of the human $\mathrm{D}_{1} \mathrm{R}$ (1:500; Sigma, St. Louis, MO) (Levey et al., 1993; Hersch et al., 1995). $\mathrm{D}_{2} \mathrm{R}$ was detected by using an affinitypurified rabbit polyclonal antiserum directed against a 28 aa sequence within the third cytoplasmic loop from the human $\mathrm{D}_{2} \mathrm{R}$ corresponding to anti-D2-284 peptide (1:500; Chemicon, Temecula, CA) that recognizes both short and long isoforms of $\mathrm{D}_{2} \mathrm{R}$ (Boundy et al., 1993). The polyclonal rabbit anti-dynorphin $\mathrm{A}$ antibody is raised against the $\mathrm{C}$-terminus part of the protein and is highly specific for dynorphin A (1:500; kindly given by Prof. G. Tramu, Talence, France). The substance P receptor neurokinin-1 (NK1) was detected by using an affinity-purified rabbit polyclonal antiserum directed against a 14 aa sequence corresponding to the C terminus of the human NK1 receptor (amino acids 393-407; 1:500; Chemicon). Met-enkephalin antibody was generated in rabbits against met-enkephalin conjugated to bovine thyroglobulin with glutaraldehyde (1:300; Immunostar, Hudson, WI). The specificity of $D_{1} R, D_{2} R$, dynorphin A, met-enkephalin, and NK1 receptor antibodies has been described in detail previously (Boundy et al., 1993; Levey et al., 1993; Mengual and Pickel, 2002; Wang and Pickel, 2002)

$\mathrm{CTb}$ single labeling. Single immunohistochemistry for CTb was performed on free-floating sections using the streptavidin-biotin-immunoperoxidase technique as described previously (Nadjar et al., 2005). After washing in PBS (0.1 M, pH 7.6), sections were incubated for $15 \mathrm{~min}$ in PBS containing $1 \% \mathrm{H}_{2} \mathrm{O}_{2}$ to quench endogenous peroxidase activity and then saturated with PBS containing 1.5\% Triton X-100 (Tx) and 4\% normal donkey serum (NDS) (Sigma). The primary antibody, anti-CTb (1:20,000), diluted in PBS/0.3\% Tx/1\% NDS, was added overnight at room temperature. After the PBS washes, sections were incubated with biotinylated donkey anti-goat IgG (Amersham Biosciences, Buckinghamshire, UK) at 1:1000 in PBS/0.3\% Tx/1\% NDS. Avidin-biotin per- 
oxidase (Vectastain Elite ABC kit; Vector Laboratories, Burlingame, CA) (Jones and Bergeron, 2004; Seppanen et al., 2005; Zachariou et al., 2006) was then added, and the peroxidase reaction product was developed using diaminobenzidine (DAB) (peroxidase substrate kit; Vector Laboratories), which gives a black precipitate when enhanced with nickel. Sections were then mounted onto gelatin-coated glass, dried, dehydrated through alcohol to xylene, and coverslipped for light microscopic analysis. Once the immunohistochemistry was completed, $\mathrm{CTb}$ injections were checked for evaluating injection area localization in either the GPi or the GPe (see Fig. 1).

Colocalization of CTb with $D_{1} R, D_{2} R$, and dynorphin A. For all immunohistochemical double labeling, $\mathrm{CTb}$ was revealed by immunofluorescence, whereas the second marker was revealed using ultra-small gold reagents amplified with silver. Double-labeling immunohistochemistry was performed incubating sections with $\mathrm{D}_{1} \mathrm{R}, \mathrm{D}_{2} \mathrm{R}$, or dynorphin $\mathrm{A}$ antibodies first. After washing in PBS, sections were saturated in PBS $/ 4 \%$ NDS and incubated in the primary antibody diluted in PBS/1\% NDS $\left(D_{1} R: 1: 500\right.$, overnight, room temperature; $\mathrm{D}_{2} \mathrm{R}: 1: 500,4 \mathrm{~d}, 4^{\circ} \mathrm{C}$; dynorphin $\mathrm{A}: 1: 500,3 \mathrm{~d}$, room temperature). Sections were incubated with the gold-coupled secondary antibody, immunogold goat anti-rat antibody $\left(\right.$ for $\left.\mathrm{D}_{1} \mathrm{R}\right)$, or donkey anti-rabbit antibody (for $\mathrm{D}_{2} \mathrm{R}$ and dynorphin) (Aurion, Biovalley, Marne la Vallee, France) diluted at 1:200 in PBS/2\% BSA acetylated (BSAc; Aurion) $/ 0.2 \%$ gelatin (Sigma). Sections were treated with $1 \%$ glutaraldehyde and $0.1 \mathrm{M}$ acetate and amplified with the HQ Silver enhancement kit (Argene SA, Varilhes, France) (Bernard et al., 1998; Dumartin et al., 1998; Jaber et al., 1999). Subsequently, sections were saturated with PBS/1.5\% Tx/4\% NDS for $1 \mathrm{~h}$ and incubated in anti-CTb antibody (1:5000) for $2 \mathrm{~d}$ at room temperature. After thorough PBS washes, sections were incubated with biotinylated donkey anti-goat IgG (Amersham Biosciences) at 1:1000 in PBS/0.3\% Tx/1\% NDS. After rinses, the signal was amplified with the tyramide signal amplification kit (PerkinElmer, Courtaboeuf, France) (Moritoyo et al., 1999; Qvigstad et al., 2002; El Meskini et al., 2005), followed by a fluorochrome Alexa 594-coupled streptavidin (Invitrogen, Eugene, OR). Sections were mounted onto gelatin-coated glass in Vectashield hardset mounting medium (Vector Laboratories) and coverslipped for light and fluorescence microscopic analysis.

Colocalization of CTb with met-enkephalin and the substance $P$ receptor NK1. The difference from the above-described protocol was that the primary antibodies directed against CTb (1:5000) and met-enkephalin (1:300) or NK1 receptor (1:500) were incubated concomitantly for $3 \mathrm{~d}$ at room temperature. $\mathrm{CTb}$ was revealed first with a fluorescent streptavidin (Invitrogen), whereas NK1 receptor and met-enkephalin were revealed next with a gold-coupled goat anti-rabbit antibody (1:200, $2 \mathrm{~h}$, room temperature; Aurion), followed by silver enhancement (Argene SA).

Imaging and data analysis. Brain sections were examined under a light and fluorescent microscope using an image analysis system (Mercator; Explora Nova, La Rochelle, France). Camera aperture, magnification, light power, and exposure time were fixed for all images. Mercator software (Explora Nova) generated images that were fed into a personal computer. Image editing software (Adobe PhotoShop; Adobe Systems, San Jose, CA) was used to stack images and adjust size, brightness, and contrast for photographs. An examiner blind to the experimental conditions analyzed the three sections per animal per immunolabeling combination. The structures of interest considered were the caudate nucleus and the putamen. The CTb-positive cells containing field were defined and delineated. For each subarea within that field, two pictures were made either under fluorescence or direct light. Images were then stacked in Photoshop (Adobe systems), and the total number of single- and double-stained cells was evaluated. The mean of double-labeled cells and SEM (when possible) were then calculated in the striatum for each group. Comparisons of distribution of MSN phenotypes were made using the frequency of distribution test ( $\chi 2$; respectively $\mathrm{df}=3$ and $p<0.05$ when $\chi^{2}=7.815$ ) (Mushiake et al., 1991).

Peptide analysis. HPLC-RIA was used to analyze the peptide levels in each brain sample (Fernandez et al., 1992, 1996). Briefly, frozen tissue was weighed, transferred to polypropylene tubes containing $1.0 \mathrm{ml}$ of boiling $0.17 \mathrm{M}$ percholic acid, and heated at $95^{\circ} \mathrm{C}$ for $7 \mathrm{~min}$. The tubes were cooled to $4^{\circ} \mathrm{C}$, and the tissue was homogenized, using a probe sonicator. The homogenate was centrifuged at $4^{\circ} \mathrm{C}$ at $30,000 \times g$ for 30 min. Supernatants were collected, and the volume was reduced in a stream of nitrogen gas. Samples were freeze-dried completely and resuspended in HPLC-grade water. After filtering through a $0.2 \mu \mathrm{m}$ filter (Waters Corporation, Milford, MA), $50 \mu \mathrm{l}$ of the sample was loaded onto the HPLC column.

The peptides were separated on a gradient of changing proportions of two solvents, solution A ( $5 \%$ acetonitrile $/ 0.1 \%$ trifluoroacetic acid) and solution B (95\% acetonitrile/0.1\% trifluoroacetic acid). These solutions were degassed by vacuum filtration. The mobile phase comprised a linear gradient of $20 \%$ B rising to $38 \%$ B over $18 \mathrm{~min}, 38 \%$ B remained constant for $5 \mathrm{~min}$, and then a gradient of $38 \% \mathrm{~B}$ falling to $20 \% \mathrm{~B}$ over $5 \mathrm{~min}$. The HPLC system consisted of a pump (Beckman 126; Beckman Coulter, Fullerton, CA), an autosampler (Beckman 507e; Beckman Coulter), an injection system with a $1 \mathrm{ml}$ sample loop, a variable wavelength ultraviolet (UV) detector (Waters Corporation), a one-channel recorder, and a fraction collector. All separations were performed at room temperature. Separations were achieved on the reversed-phase C12 column (MaxRP4, $250 \times 4.6 \mathrm{~mm}, 4 \mu \mathrm{m}$ particle size; Phenomenex, Torrance, CA) preceded by a guard column. The flow rate was $1 \mathrm{ml} / \mathrm{min}$. UV absorbance was measured at $210 \mathrm{~nm}$ to identify peaks with the same retention time as the peptides of interest. Fractions containing the peptides of interest were collected in polypropylene tubes after the detected peak emerged from the column, lyophilized, and stored at $-80^{\circ} \mathrm{C}$ for RIA. Commercial RIA kits for leucine (leu)-enkephalin, met-enkephalin, $\alpha$-neoendorphin, and dynorphin $\mathrm{A}_{1-13}$ were obtained from Peninsula Laboratories (San Carlos, CA) and used to detect the peptides according to the manufacturer's instructions. ${ }^{125}$ I peptide was used as the RIA radioligand. For each peptide and region, the ratio of peptide level given is relative to its content in the striatum as an index of relative presence in the different structures.

\section{Results}

\section{Selection of CTb injection sites}

Selection of injection sites specifically restricted to the GPe or GPi (Fig. $1 A$ ) was controlled by revealing CTb localization by immunohistochemistry (Fig. $1 B a, B b$ ). We retained only the sites that were perfectly limited to a single structure. Of 32 injections performed, 10 injection sites fulfilled all the selection criteria, three in GPi and seven in GPe (Fig. 1A). Although mostly fibers were seen at the injection site, retrogradely labeled areas demonstrated cellular bodies of striatofugal neurons (Fig. $1 \mathrm{Ca}, \mathrm{Cb}$ ). The CTb staining appeared very localized in the caudate nucleus and putamen, which is a marker of injection accuracy. As a negative control, we checked that no cell bodies were stained in the striatum when CTb was injected outside of the pallidal complex. Figure $1 D$ shows an example of CTb injection into the thalamus along the white matter. No cell bodies were visible in the caudate nucleus (Fig. $1 D c$ ) or in the putamen (Fig. $1 D d$ ).

\section{Phenotype of striatal CTb-positive neurons}

\section{Colocalization of CTb with DARs $D_{1}$ and $D_{2}$}

Figure 2 shows representative microphotographs of $C T b / D_{1} R$ (Fig. $2 A$ ) and $\mathrm{CTb} / \mathrm{D}_{2} \mathrm{R}$ (Fig. $2 \mathrm{~B}$ ) colocalization. When demonstrated by immunofluorescence (Fig. $2 A a, B a$ ), CTb had a similar pattern of distribution to that detected with a precipitate of DAB (Fig. $1 B, C$ ). When detected with $\mathrm{UV}$ light or direct light, $\mathrm{D}_{1} \mathrm{R}$ (Fig. $2 A b 1, A b 2)$ and $\mathrm{D}_{2} \mathrm{R}($ Fig. $2 \mathrm{Bb} 1, \mathrm{Bb} 2)$ labeling demonstrated full, round MSN-like cells. Superimposing both labels clearly showed that some CTb-positive cells also expressed either $D_{1} \mathrm{R}$ or $\mathrm{D}_{2} \mathrm{R}$ (Fig. $2 A c 1, A c 2, B c 1, B c 2$, double arrows), whereas some did not (Fig. $2 A c 1, A c 2, B c 1, B c 2$, arrows). This pattern of colocalization was seen in all treatment groups

\section{Colocalization of CTb with NK1 receptor, dynorphin A, and met-enkephalin}

The same immunodetection technique was used for evaluating the colocalization of $\mathrm{CTb}$ with opioid peptides. Direct light was used to observe NK1 receptor, dynorphin A, and met-enkephalin 
staining. CTb still appeared in red (Fig. $3 A-C)$. NK1 receptor-positive cells corresponded to large cholinergic interneuronlike cells (Fig. 3D). Dynorphin A and metenkephalin labelings highlighted small MSN-like cells (Fig. $3 E, F$ ). NK1 receptor and CTb were never colocalized (Fig. $3 G$ ), whereas dynorphin A and met-enkephalin were (Fig. $3 H, I$ ).

Quantification of CTb colocalization with DARs and opioid peptides

For quantification, we considered only the CTb-positive cells and compared the number of colocalized cells to the total number of CTb-positive cells. On every section, all CTb-positive cells were considered.

Wherever the injection site (i.e., GPi or $\mathrm{GPe}$ ) or whatever experimental condition (i.e., control, parkinsonian, nondyskinetic, or dyskinetic NHPs), NK1 receptor immunostaining was never colocalized with CTb (Figs. 3-5). The NK1 receptor staining being only observable on large cholinergic interneurons defined from their shape further supports the specificity of the $\mathrm{CTb}$ retrograde labeling of the MSN (i.e., the striatofugal neurons).

Striatal neurons projecting to $\mathrm{GPi}$ showed immunolabeling for $\mathrm{D}_{1} \mathrm{R}, \mathrm{D}_{2} \mathrm{R}$, dynorphin A, or met-enkephalin (Fig. 4) and not only for $\mathrm{D}_{1} \mathrm{R}$ and dynorphin $\mathrm{A}$, as classically viewed. Despite some slight variations, in terms of $D_{1} R$ and $D_{2} R$ expression by cells projecting to the GPi in the different experimental conditions, striatal cells projecting to the GPi did not display drastic phenotypic modifications in the parkinsonian or dyskinetic states (Fig. 4). No significant differences were observed between groups (Fig. $4 F$ ). On average, $72.9 \pm 11.4 \%$ of the striato-GPi neurons expressed $\mathrm{D}_{1} \mathrm{R}$, whereas $73.9 \pm$ $13.6 \%$ of the striato-GPi neurons expressed $\mathrm{D}_{2} \mathrm{R}$. Moreover, $91.9 \pm 2.8 \%$ of the striato-GPi neurons expressed dynorphin $\mathrm{A}$, whereas $51.4 \pm 1.4 \%$ of the striatoGPi neurons expressed met-enkephalin.

Striatal neurons projecting to GPe showed immunolabeling for $D_{1} R, D_{2} R$, dynorphin A, or met-enkephalin (Fig. 5), and not only for $\mathrm{D}_{2} \mathrm{R}$ and met-enkephalin, as classically viewed. As for the striato-GPi neurons, the striato-GPe neurons did not show marked differences in the parkinsonian, non-dyskinetic, or dyskinetic states (Fig. 5). An average of $78.9 \pm 6.4 \%$ of the striatoGPe neurons expressed $D_{1} R$, whereas $87.3 \pm 4.0 \%$ of the striatoGPe neurons expressed $\mathrm{D}_{2} \mathrm{R}$. Furthermore, $85.8 \pm 10.1 \%$ of the striato-GPe neurons expressed dynorphin A, whereas $63.0 \pm$ $6.0 \%$ of the striato-GPe neurons expressed met-enkephalin. No significant differences were observed between groups (Fig. $5 F$ ).

Together, these results support the notion that striatofugal

B
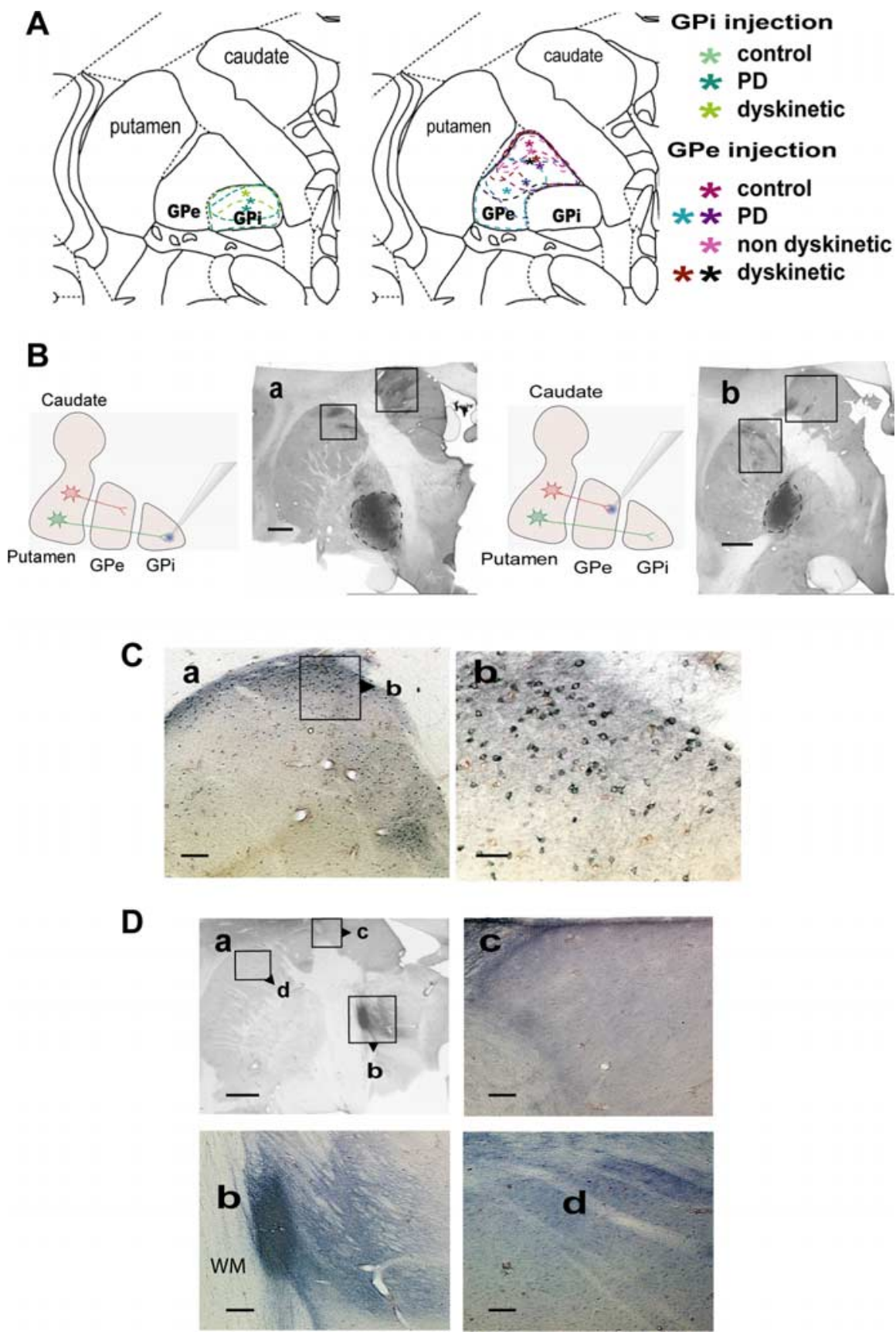

Figure 1. Validation of CTb injection sites. $A$, Schematic diagram illustrating location of (Tb injection in GPi (left) or GPe (right). Each asterisk represents the central point of CTb injection for a given NHP, whereas the dashed circle delineates the injection area. $\boldsymbol{B}$, Microphotographs illustrating representative CTb injection sites in the GPi $(\boldsymbol{a})$ and GPe $(\boldsymbol{b})$. CTb was revealed by nickel-DAB immunohistochemistry that gives a black precipitate. Squares, Retrogradely labeled areas; dashed circles, injection areas. Scale bars, $20 \mu \mathrm{m}$. $\boldsymbol{C}$, Microphotograph highlight of putamen retrogradely labeled from $\operatorname{GPe}(\boldsymbol{a}, \boldsymbol{b})$ at a higher magnification than $\boldsymbol{B} \boldsymbol{b}$. $\boldsymbol{b}$ is a magnification of $\boldsymbol{a}$. Scale bars: $\boldsymbol{a}, 100 \mu \mathrm{m} ; \boldsymbol{b}, 50 \mu \mathrm{m}$. $\boldsymbol{D}$, Negative control of CTb injection. In this example, CTb was injected in the thalamus, along the white matter $(\boldsymbol{a}, \boldsymbol{b})$. In $\boldsymbol{c}$ and $\boldsymbol{d}$, no stained neurons are observed in the caudate or the putamen. $\boldsymbol{b}$ - $\boldsymbol{d}$ are magnifications of $\boldsymbol{a}$. Scale bars: $\boldsymbol{a}, 20 \mu \mathrm{m} ; \boldsymbol{b}, 400 \mu \mathrm{m} ; \boldsymbol{c}, \boldsymbol{d}, 100 \mu \mathrm{m}$. WM, White matter.

neurons projecting massively to either the GPe or the GPi might not be as segregated as classically considered and that their phenotype is not affected by the experimental situation.

\section{Identity of opioid peptides in the pallidal complex}

The observation that such a number of striato-GPe and striatoGPi neurons also expressed dynorphin A and met-enkephalin, respectively, prompted us to define (and quantify) the identity of mRNA-derived preproenkephalin-A (PPE-A) and PPE-B, as well 

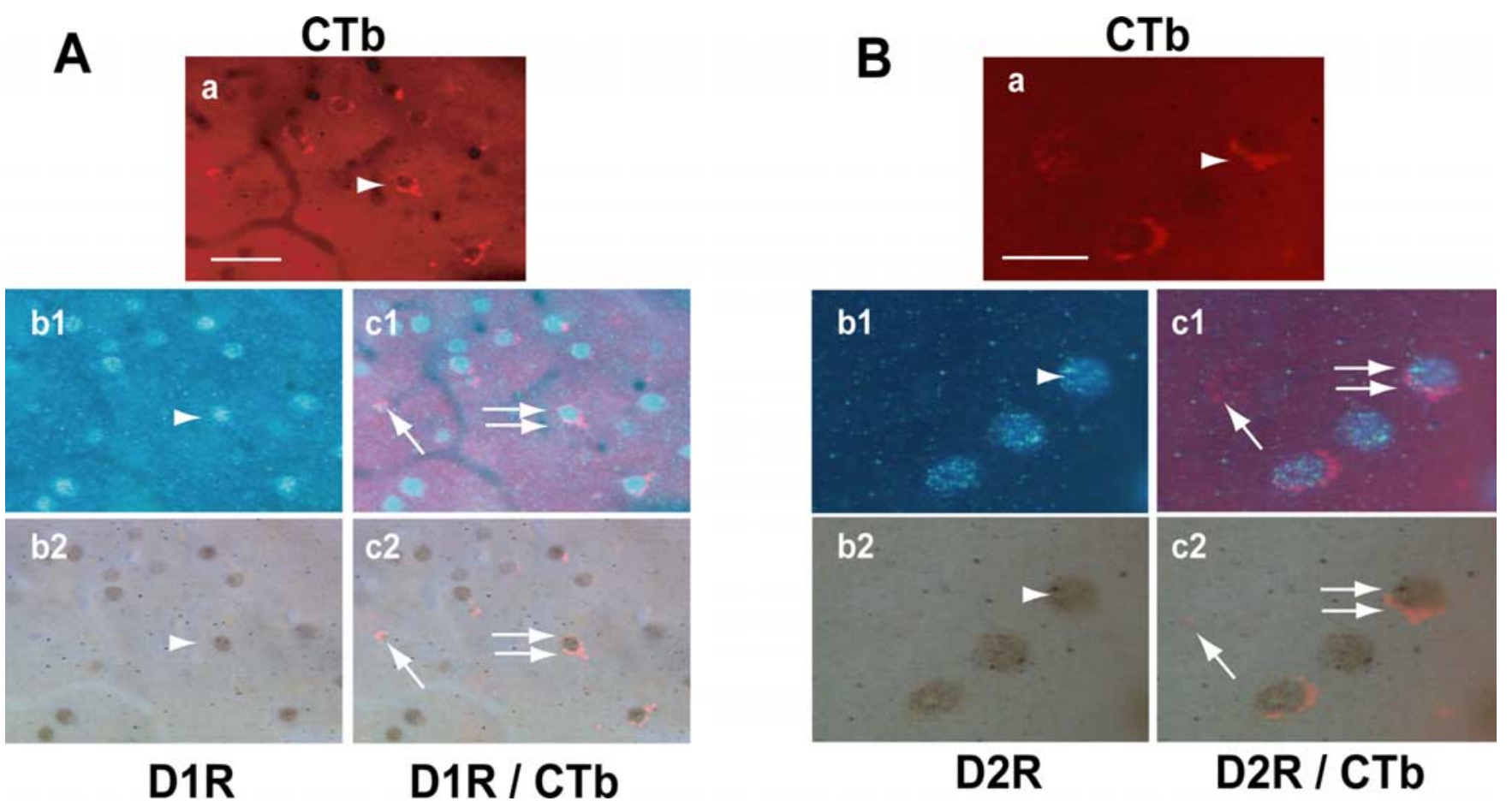

Figure 2. Colocalization of $C T$ b with $D_{1} R(A)$ or $D_{2} R(B)$. Microphotographs representing double staining of $C T b$ with $D_{1} R$ and $D_{2} R$ are shown. (Tb labeling appears in red $(\boldsymbol{a}$, arrowhead), whereas $D_{1} R$ and $D_{2} R$ appear either in blue ( $\boldsymbol{b} 1$, UV light, arrowhead) or in brown ( $\boldsymbol{b} 2$, direct light, arrowhead). Overlapping of (Tb and $D_{1} R$ or $D_{2} R$ is visible as seen on microphotographs $\boldsymbol{c} 1$ (arrows) and $\boldsymbol{c} 2$ (arrows). The double arrows in $\mathbf{c} 1$ and $\mathbf{c} 2$ show double staining. Scale bars: $A, 50 \mu \mathrm{m} ; \boldsymbol{B}, 25 \mu \mathrm{m}$.

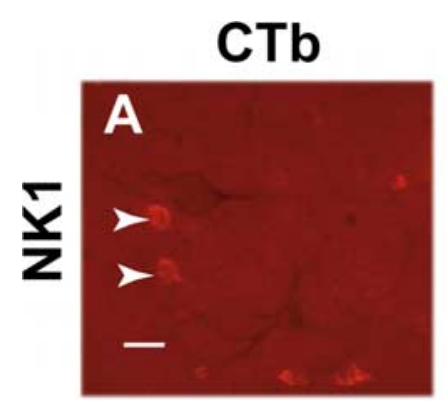

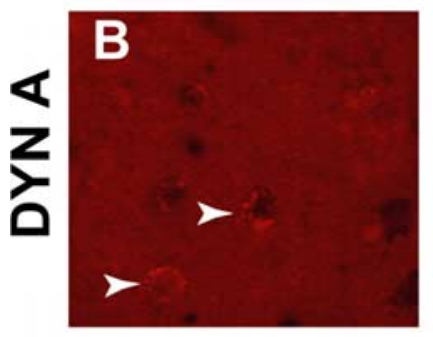

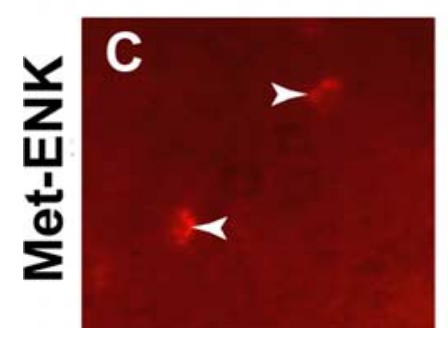

\section{marker}

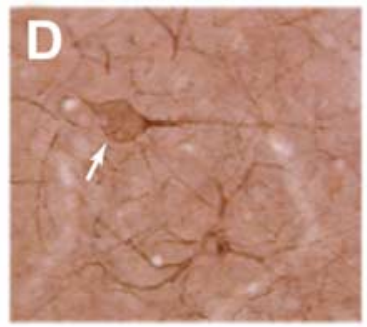

\section{CTb / marker}
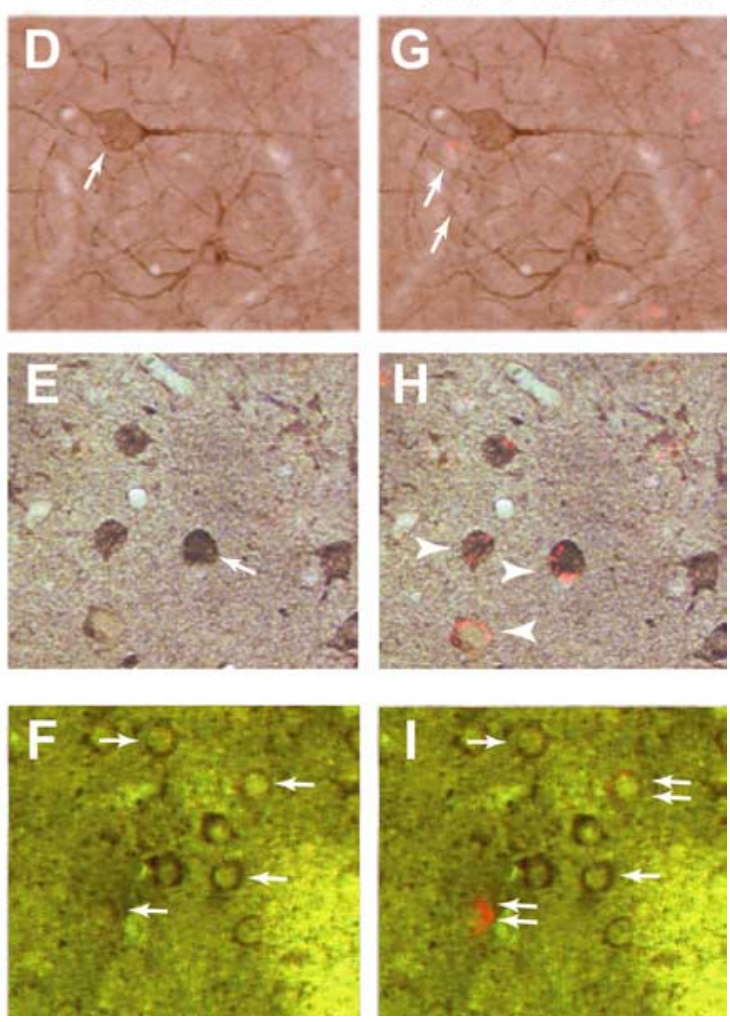
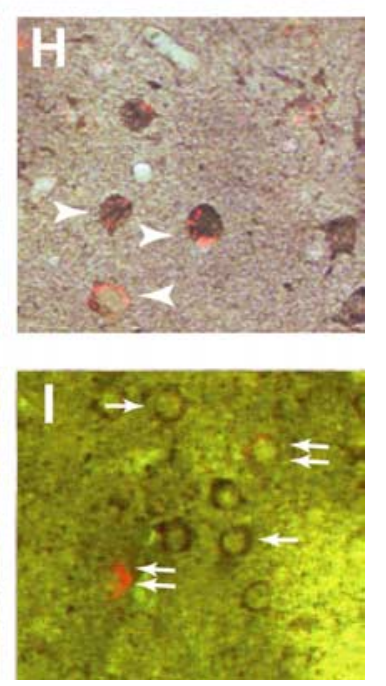

Figure 3. Colocalization of $\mathrm{CTb}$ with opioid peptides. Microphotographs representing double staining of CTb with NK1 receptor, dynorphin $A$, and met-enkephalin are shown. $\boldsymbol{A}-\boldsymbol{F}$, (Tb appears in red $(\boldsymbol{A}-\boldsymbol{C}$, arrowheads), whereas NK1 receptor $(\boldsymbol{D})$, dynorphin $A(\boldsymbol{E})$, and met-enkephalin $(\boldsymbol{F})$ appear in brown (arrows). $\mathbf{G}$, NK1 receptor and CTb (arrows) are never colocalized. $\boldsymbol{H}$, Overlapping of (Tb and dynorphin A (arrowheads). $I$, Overlapping of (Tb and met-enkephalin (double arrows). The arrow shows single-stained met-enkephalin-positive cells. Scale bar (in A), $50 \mu \mathrm{m}$. DYN A, Dynorphin A; Met-ENK, met-enkephalin as mRNA-derived opioid peptides in the striatum, GPe, and GPi of normal animals. Leu-enkephalin, $\alpha$-neoendorphin, and dynorphin A, all resulting from PPE-B mRNA translation (Civelli et al., 1985) and classically related to the direct pathway (Augood et al., 1989; Asselin et al., 1994; Jolkkonen et al., 1995), were mostly expressed in the GPi but also found in the GPe (Table 1). Met-enkephalin that derives from PPE-A mRNA (Beaumont et al., $1985)$ and is classically related to indirect pathway neurons (Augood et al., 1989; Asselin et al., 1994; Jolkkonen et al., 1995) was found at similar levels in both pallidal segments (Table 1). These results further support the notion that the different striatofugal neuronal populations project toward both GPe and GPi (Fig. 6).

\section{Discussion}

The present data support the concept that striatofugal neurons projecting massively to either the GPe or the GPi might not be as segregated as classically considered. They also suggest that functional colocalization of both DAR subtypes as well as the opioid peptides, met-enkephalin and dynorphin $\mathrm{A}$, occur in those striatofugal neurons. Finally, the present results show that the phenotype of striatofugal neurons, and therefore their relative influence on target structures, is preserved after DA denervation in the parkinsonian state and af- 
A
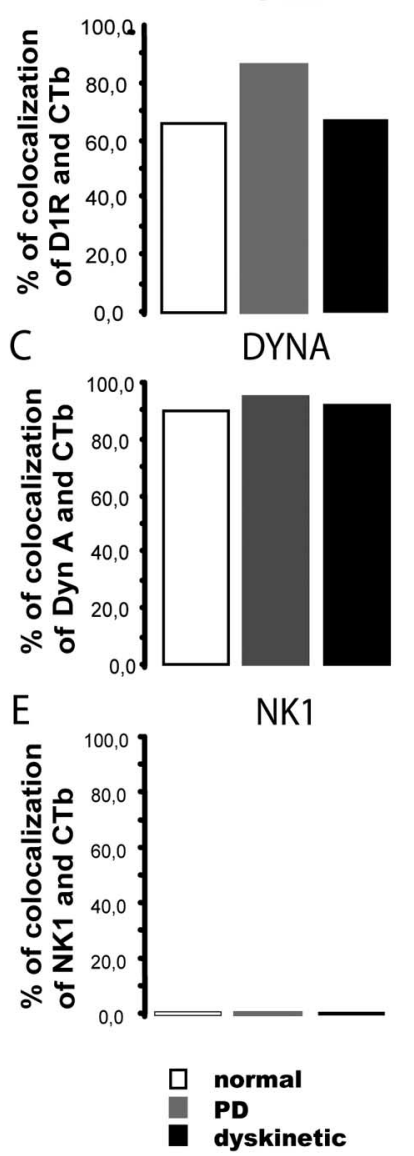

B
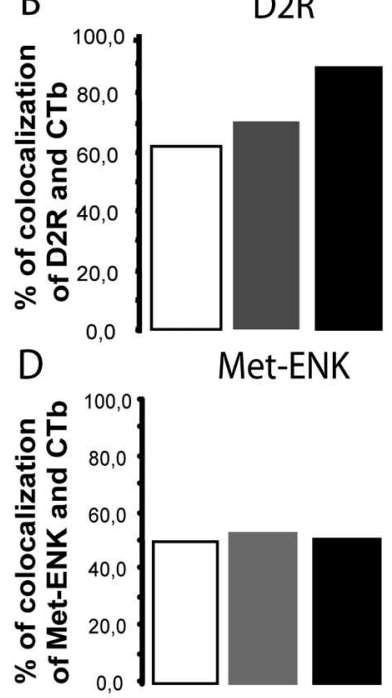

$\mathrm{F}$

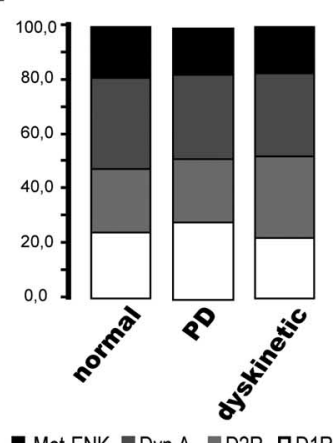

A

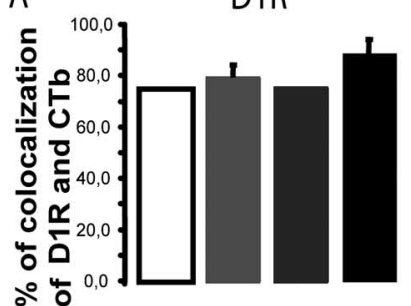

C

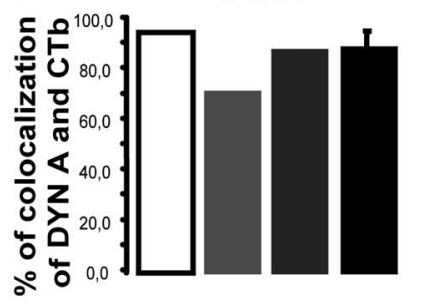

$\mathrm{E}$

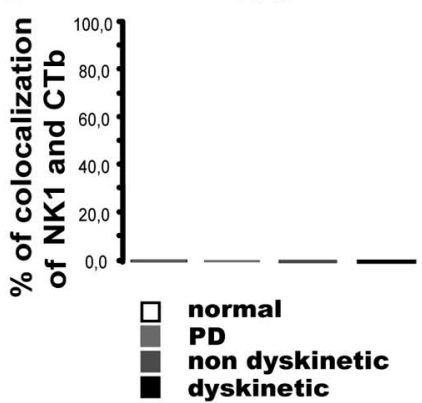

B

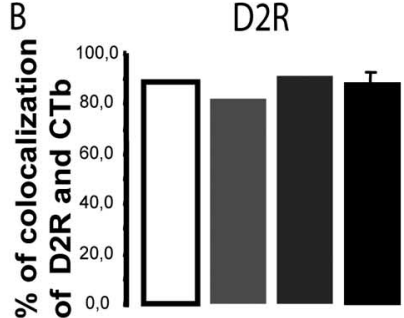

D

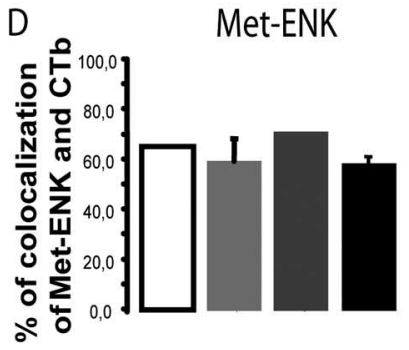

\section{$\mathrm{F}$}

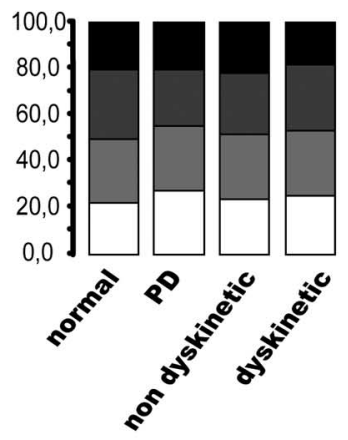

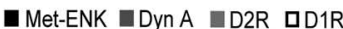

Figure 4. Phenotype of MSNs projecting to the GPi in the different physiopathological conditions. $A-E$, Bar graphs summarize the percentage of $\left(T b\right.$-positive cells colocalized with $D_{1} R$ $(\boldsymbol{A}), D_{2} R(\boldsymbol{B})$, dynorphin $A(D Y N A ; C$, met-enkephalin (Met-ENK; $\boldsymbol{D}$ ), and NK1 receptor $(\boldsymbol{E})$ after CTb injection in GPi. $\boldsymbol{F}$, Synthetic graphic representation of the relative percentage distribution of the different protein marker in the different experimental conditions. The left column shows a summary of graphs $\boldsymbol{A}-\boldsymbol{E}$ in normal conditions, the middle column corresponds to the parkinsonian state, the right column shows results in dyskinetic conditions. Note that the pathophysiological status of the animal has no significant effect on the pattern of phenotypic characterization $(\boldsymbol{F}) . n=1$ for each situation.

ter additional chronic L-dopa treatment in both nondyskinetic and dyskinetic groups. This suggests that the phenotypic plasticity of the striatofugal system is not affected by the experimental condition.

The present study shows that the majority of striatofugal neurons projecting to the GPe and the GPi express $D_{1} R$ and $D_{2} R$ or dynorphin A and met-enkephalin. Three hypotheses might explain this result. (1) A previously unknown population of $D_{1} R$ and dynorphin A-positive neurons would project solely to GPe, whereas a population of $\mathrm{D}_{2} \mathrm{R}$ - and met-enkephalin-positive neurons would project solely to GPi. (2) The indirect and direct pathways are still distinct anatomically, but a decent proportion of their cells (maybe 40\%) has D1R/D2R/enkephalin/dynorphin in the same neurons. (3) Alternatively, projections of striatofugal neurons would not be as segregated as previously thought; instead, neurons would send collaterals into both segments of the pallidum. We and others have previously suggested from retrograde fluorescent double-labeling studies in animals that the striatofugal fiber system is composed of separate subsystems terminating in either the GPe or the GPi (Féger and Crossman, 1984; Parent et al., 1984, 1989; Selemon and Goldman-Rakic, 1990).

Figure 5. Phenotype of MSNs projecting to the GPe in the different physiopathological conditions. $\boldsymbol{A}-\boldsymbol{E}$, Bar graphs summarize the number of CTb-positive cells colocalized with $D_{1} R(\boldsymbol{A})$, $\mathrm{D}_{2} \mathrm{R}(\boldsymbol{B})$, dynorphin $\mathrm{A}$ (DYNA; $\boldsymbol{C}$, met-enkephalin (Met-ENK; $\boldsymbol{D}$ ), and NK1 receptor $(\boldsymbol{E})$. $\boldsymbol{F}$, Synthetic graphic representation of the relative percentage distribution of the different protein markers in the different experimental conditions. The left column shows a summary of graphs $\boldsymbol{A}-\boldsymbol{E}$ in normal conditions, the second column corresponds to the parkinsonian state, the third column represents the nondyskinetic state, and the right column shows results in dyskinetic conditions. Note that the pathophysiological status of the animal has no significant effect on the pattern of phenotypic characterization $(\boldsymbol{F})$. Normal and nondyskinetic, $n=1 ; \mathrm{PD}, n=1$ or 2 ; dyskinetic, $n=3$.

Table 1. Relative amounts of opioid peptides

\begin{tabular}{llllr}
\hline & Met-ENK & Leu-ENK & $\alpha$-Neo & DYN A \\
\hline Striatum & 1.0 & 1.0 & 1.0 & 1.0 \\
GPe & 1.1 & 0.9 & 0.8 & 1.2 \\
GPi & 0.9 & 0.9 & 8.7 & 12.8
\end{tabular}

Levels of leu-enkephalin (Leu-ENK), met-enkephalin (Met-ENK), $\alpha$-neoendorphin ( $\alpha$-Neo), and dynorphin A (DYN A) were assessed by HPLC-RIA in the striatum, GPe, and GPi. Ratios of peptides levels are given in relation to the striatum.

Such a view contributed to the now classical concept of basal ganglia organization (Alexander and Crutcher, 1990; Albin et al., 1995). However, at variance with those early results, single-axon tracing experiments clearly demonstrate that the majority of primate striatofugal neurons arborizes in the three major target structures of the striatum (i.e., GPe, GPi, and SNr), through highly collateralized axons (Hazrati and Parent, 1992; Parent and Hazrati, 1994; Parent et al., 1995; Levesque and Parent, 2005) (Fig. 6).

Striatofugal axons that branch into more than one target site have been evaluated at $\sim 90 \%$ of the total number of neurons 


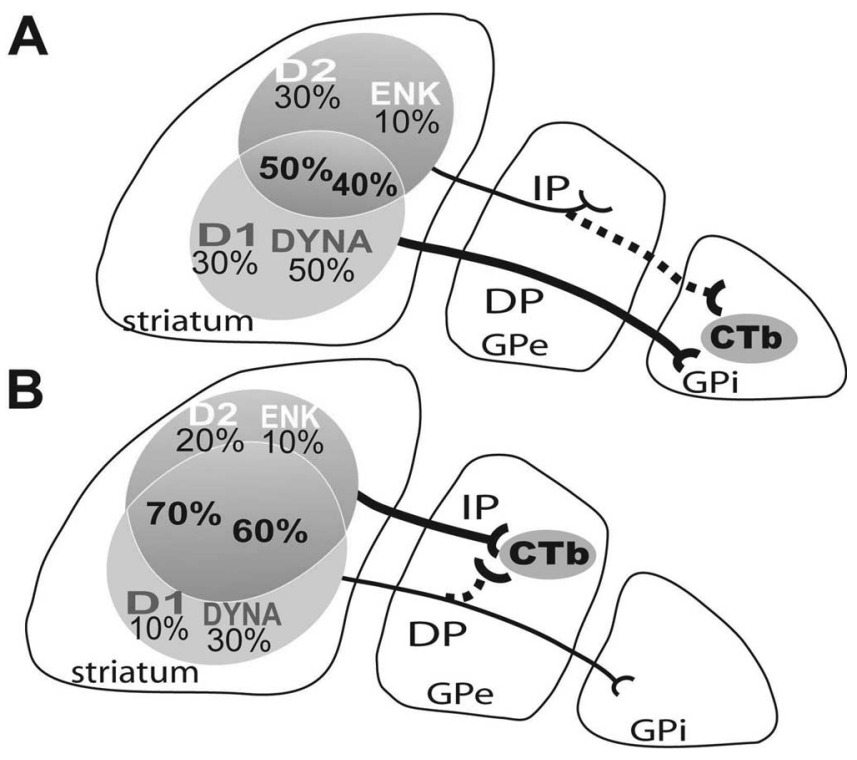

Figure 6. Schematic representation of CTb colocalization with DARs or opioid peptides in striatal neurons projecting either to the GPe or GPi. A, Quantitative results of CTb colocalization with DARs or opioid peptides while CTb was injected in the GPi with deduced overlap between $D_{1} R$ and $D_{2} R$ or between dynorphin $A$ - and enkephalin-positive cells, suggesting coexpression. $B$, Quantitative results of CTb colocalization with DARs or opioid peptides while CTb was injected in the GPe with deduced overlap between $D_{1} R$ and $D_{2} R$ or between dynorphin $A$ - and enkephalin-positive cells, suggesting coexpression. DYNA, Dynorphin A; ENK, enkephalin; DP, direct pathway; IP, indirect pathway.

(Levesque and Parent, 2005). However, the functional importance of such collateralization had not been investigated because only a relatively limited number of neurons were analyzed. The present work gives the opportunity to assess the importance of branching of striatofugal neurons. Considering striatal neurons projecting to the GPi, for example, shows that a large number of these cells express $\mathrm{D}_{1} \mathrm{R}(\approx 80 \%)$ and dynorphin $\mathrm{A}(\approx 90 \%)$. However, $75 \%$ are also $\mathrm{D}_{2} \mathrm{R}$ positive, and $50 \%$ are met-enkephalin positive. This suggests that collaterals of indirect pathway axons would represent a large part of GPi innervation from the striatum (Fig. 6). It also suggests that coexpression of $D_{1} R$ and $D_{2} R$ on one hand and of met-enkephalin and dynorphin A on the other hand might occur (see below). The same reasoning could be applied to GPe innervation by striatal neurons.

However, it is also possible that these dually projecting afferents represent "fibers of passage" that are capable of transporting $\mathrm{CTb}$ and are essentially distally projecting afferents (Chen and Aston-Jones, 1995). Therefore, the retrograde labeling would overestimate the size of the projection from the striatum to GPe by revealing also striato-GPi "en-passage" fibers. CTb is not significantly uptaken by intact axons passing through an injection site but lesioned axons take it up easily (Chen and Aston-Jones, 1995). The total lack of tracks left by the micropipettes $(8-10 \mu \mathrm{m}$ tip diameter) suggests that lesions, if any, were minimal and could not account for the greater apparent proportion of cells expressing direct and indirect pathway markers after injection in the GPe than is seen after injecting in the GPi (Fig. 6). We do propose that, instead, it reflects a higher number of collaterals from the direct pathway striatofugal neurons toward the GPe than from the indirect pathway striatofugal neurons toward the GPi.

These results are further supported by the reversed-phase HPLC-RIA analysis of opioid peptide levels. Here again, segregation between direct and indirect pathway projections is chal- lenged because opioid peptides of the direct pathway are present in the GPe (i.e., dynorphin A, leu-enkephalin, $\alpha$-neoendorphin) and those of the indirect pathway are present in the GPi (i.e., met-enkephalin), in normal conditions. Therefore, all of these results are at odds with the concept of a dual striatofugal system and call for a reappraisal of our current concept of the anatomical and functional organization of primate basal ganglia in normal and pathological conditions.

Our results suggest some colocalization between $D_{1} R$ and $\mathrm{D}_{2} \mathrm{R}$, as well as between met-enkephalin and dynorphin A. Relatively strict segregation still constitutes the prevalent view. Indeed, double in situ hybridization with $\mathrm{D}_{1} \mathrm{R}$ and $\mathrm{D}_{2} \mathrm{R}$ cRNA probes demonstrates prominent segregation of $D_{1} R$ and $D_{2} R$ mRNAs in distinct neuronal populations of the dorsal and ventral striatum both in the rat (Le Moine and Bloch, 1995) and primate (Aubert et al., 2000). Such studies were in keeping with rodent studies demonstrating a high coexpression of dopamine $D_{1} R$ and substance $P$ mRNAs on one hand and of $D_{2} R$ and preproenkephalin A mRNAs on the other hand, with little coexpression of DARs or of peptide precursors (Gerfen and Young, 1988; Gerfen et al., 1990; Harrison et al., 1990). Although "segregation" was supported by previous studies, a significant number of $D_{1} R$ and $\mathrm{D}_{2} \mathrm{R}$-coexpressing neurons (5\%) were found in both species (Le Moine and Bloch, 1995; Aubert et al., 2000). Coexpression of enkephalin, substance $\mathrm{P}$, and dynorphin peptides in striatal neurons has also been detected (Penny et al., 1986; Besson et al., 1990; Anderson and Reiner, 1991). A recent rat study combining single-cell reverse transcripton-PCR, in situ hybridization, and immunohistochemical studies of substance $\mathrm{P}$ and enkephalin revealed a 3-4\% co-occurrence in striatofugal neurons (Wang et al., 2006). We acknowledge that our quantitative approach might be more sensitive than double in situ hybridization and probably overestimates the exact proportion of colocalization between $\mathrm{D}_{1} \mathrm{R}$ and $\mathrm{D}_{2} \mathrm{R}(\sim 50 \%)$ (Fig. 6). However, considering the studies demonstrating a significant coexistence of both DARs on striatal neurons (Akaike et al., 1987; Ohno et al., 1987; Surmeier et al., 1996; Aizman et al., 2000) and the low sensitivity of double in situ hybridization, it seems sensible to propose that the proportion of colocalization is in-between and that it should have a functional impact on basal ganglia physiology.

Finally, the key add-on of this study was to assess changes in MSN phenotype in primates with a clinical status that closely resemble those characteristics displayed by $\mathrm{PD}$ patients. It is generally assumed that the phenotype of striatal cells remains constant in both normal and disease states. However, no evidence existed to either support or refute this assumption. It is well established that PPE-A mRNA for the primary precursor of met-enkephalin is upregulated in parkinsonism, whereas the PPE-B precursor for dynorphin A, leu-enkephalin, and $\alpha$-neoendorphin is downregulated (Herrero et al., 1995; Morissette et al., 1997; Tel et al., 2002; Henry et al., 2003). Chronic L-dopa treatment leading to dyskinesia further deregulates their expression with an overexpression of PPE-B mRNA, for instance (Morissette et al., 1999; Tel et al., 2002; Aubert et al., 2006). It is believed that such changes in opioid expression are important in the mechanisms generating parkinsonian symptoms and L-dopainduced dyskinesia. Although our extremely rigorous selection criteria reduced some groups to a single animal, the present study is the first to suggest that these expression variations are unlikely the consequence of an ectopic expression of opioid peptide precursor in cells that would not normally express them, but are rather attributable to synthesis levels modifications inside of the original cells. 
Although our experimental paradigm leads us to propose that no clear phenotypic variations are observed in different pathophysiological conditions, it does not mean that plastic changes do not occur in the striatum. For instance, it has been shown that the size of the dendritic tree and the density of dendritic spines of MSNs is significantly reduced in the caudate nucleus and the putamen of PD patients compared with controls (Stephens et al., 2005), confirming previous data in rodents (Ingham et al., 1998). The MSNs submitted to this dramatic plastic change were recently characterized as the $\mathrm{D}_{2} \mathrm{R}$-immunopositive neurons (Day et al., 2006); however, their impact on MSN physiology is still unclear. Altogether, our present data and these previous results support the idea of plastic changes in the corticostriatal network but with no consequence, postsynaptically, on the phenotype of striatal neurons. Thus, loss of cortical afferents appears unlikely to affect the phenotypic pattern of striatal neurons, but rather might alter their activity or mRNA processing (Day et al., 2006).

\section{Conclusions}

The present study leads to three major conclusions: (1) we show for the first time that the phenotype of striatal neurons is unchanged in the parkinsonian or L-dopa-treated states compared with the control situation; (2) we argue in favor of axonal collateralization of striatofugal cells; and (3) we argue in favor of coexpression of $D_{1} R$ and $D_{2} R$, as well as the different opioid peptides in striatofugal neurons. On the basis of these quantitative findings in different experimental conditions, our study calls for a reappraisal of the current concept of basal ganglia organization. Additional studies are needed to understand the physiological meaning of such convergence/divergence of the striatofugal neurons on their basal ganglia targets.

\section{References}

Aizman O, Brismar H, Uhlen P, Zettergren E, Levey AI, Forssberg H, Greengard P, Aperia A (2000) Anatomical and physiological evidence for D-1 and D-2 dopamine receptor colocalization in neostriatal neurons. Nat Neurosci 3:226-230.

Akaike A, Ohno Y, Sasa M, Takaori S (1987) Excitatory and inhibitory effects of dopamine on neuronal activity of the caudate nucleus neurons in vitro. Brain Res 418:262-272.

Albin RL, Young AB, Penney JB (1995) The functional anatomy of disorders of the basal ganglia. Trends Neurosci 18:63-64.

Alexander GE, Crutcher MD (1990) Functional architecture of basal ganglia circuits: neural substrates of parallel processing. Trends Neurosci 13:266-271.

Anderson KD, Reiner A (1991) Striatonigral projection neurons: a retrograde labeling study of the percentages that contain substance P or enkephalin in pigeons. J Comp Neurol 303:658-673.

Asselin MC, Soghomonian JJ, Côté PY, Parent A (1994) Striatal changes in preproenkephalin mRNA levels in parkinsonian monkeys. NeuroReport 5:2137-2140.

Aubert I, Ghorayeb I, Normand E, Bloch B (2000) Phenotypical characterization of the neurons expressing the D1 and D2 dopamine receptors in the monkey striatum. J Comp Neurol 418:22-32.

Aubert I, Guigoni C, Hakansson K, Li Q, Dovero S, Barthe N, Bioulac BH, Gross CE, Fisone G, Bloch B, Bezard E (2005) Increased D1 dopamine receptor signaling in levodopa-induced dyskinesia. Ann Neurol 57:17-26.

Aubert I, Guigoni C, Li Q, Dovero S, Bioulac BH, Gross CE, Crossman AR, Bloch B, Bezard E (2006) Enhanced preproenkephalin-B-derived opioid transmission in striatum and subthalamic nucleus converges upon globus pallidus internalis in L-dopa-induced dyskinesia. Biol Psychiatry, in press.

Augood SJ, Emson PC, Mitchell IJ, Boyce S, Clarke CE, Crossman AR (1989) Cellular localisation of enkephalin gene expression in MPTP-treated cynomolgus monkeys. Brain Res Mol Brain Res 6:85-92.

Beaumont A, Metters KM, Rossier J, Hughes J (1985) Identification of a proenkephalin precursor in striatal tissue. J Neurochem 44:934-940.

Bernard V, Laribi O, Levey AI, Bloch B (1998) Subcellular redistribution of $\mathrm{m} 2$ muscarinic acetylcholine receptors in striatal interneurons in vivo after acute cholinergic stimulation. J Neurosci 18:10207-10218.

Besson MJ, Graybiel AM, Quinn B (1990) Co-expression of neuropeptides in the cat's striatum: an immunohistochemical study of substance $\mathrm{P}$, dynorphin B and enkephalin. Neuroscience 39:33-58.

Bezard E, Dovero S, Prunier C, Ravenscroft P, Chalon S, Guilloteau D, Bioulac B, Brotchie JM, Gross CE (2001) Relationship between the appearance of symptoms and the level of nigrostriatal degeneration in a progressive MPTP-lesioned macaque model of Parkinson's disease. J Neurosci 21:6853-6861.

Bezard E, Ferry S, Mach U, Stark H, Leriche L, Boraud T, Gross CE, Sokoloff P (2003) Attenuation of levodopa-induced dyskinesia by normalizing dopamine D3 receptor function. Nat Med 9:762-767.

Bolam JP (1992) Preparation of central nervous system tissue for light and electron microscopy. In: Experimental neuroanatomy: a practical approach (Rickwood D, Hames BD, eds), pp 1-29. New York: Oxford UP.

Boundy VA, Luedtke RR, Artymyshyn RP, Filtz TM, Molinoff PB (1993) Development of polyclonal anti-D2 dopamine receptor antibodies using sequence-specific peptides. Mol Pharmacol 43:666-676.

Chen S, Aston-Jones G (1995) Evidence that cholera toxin B subunit (CTb) can be avidly taken up and transported by fibers of passage. Brain Res 674:107-111.

Civelli O, Douglass J, Goldstein A, Herbert E (1985) Sequence and expression of the rat prodynorphin gene. Proc Natl Acad Sci USA 82:4291-4295.

Day M, Wang Z, Ding J, An X, Ingham CA, Shering AF, Wokosin D, Ilijic E, Sun Z, Sampson AR, Mugnaini E, Deutch AY, Sesack SR, Arbuthnott GW, Surmeier DJ (2006) Selective elimination of glutamatergic synapses on striatopallidal neurons in Parkinson disease models. Nat Neurosci 9:251-259.

Dumartin B, Caille I, Gonon F, Bloch B (1998) Internalization of $\mathrm{D}_{1}$ dopamine receptor in striatal neurons in vivo as evidence of activation by dopamine agonists. J Neurosci 18:1650-1661.

El Meskini R, Cline LB, Eipper BA, Ronnett GV (2005) The developmentally regulated expression of Menkes protein ATP7A suggests a role in axon extension and synaptogenesis. Dev Neurosci 27:333-348.

Féger J, Crossman AR (1984) Identification of different subpopulations of neostriatal neurones projecting to globus pallidus or substantia nigra in the monkey: a retrograde fluorescence double-labelling study. Neurosci Lett 49:7-12.

Fernandez A, de Ceballos ML, Jenner P, Marsden CD (1992) Striatal neuropeptide levels in Parkinson's disease patients. Neurosci Lett 145: 171-174.

Fernandez A, de Ceballos ML, Rose S, Jenner P, Marsden CD (1996) Alterations in peptide levels in Parkinson's disease and incidental Lewy body disease. Brain 119:823-830.

Georges F, Aston-Jones G (2002) Activation of ventral tegmental area cells by the bed nucleus of the stria terminalis: a novel excitatory amino acid input to midbrain dopamine neurons. J Neurosci 22:5173-5187.

Gerfen CR, Young WS (1988) Distribution of striatonigral and striatopallidal peptidergic neurons in both patch and matrix compartments: an in situ hybridization histochemistry and fluorescent retrograde tracing study. Brain Res 460:161-167.

Gerfen CR, Engber TM, Mahan LC, Susel Z, Chase TN, Monsma FJ, Sibley DR (1990) D1 and D2 dopamine receptor-regulated gene expression of striatonigral and striatopallidal neurons. Science 250:1429-1432.

Guigoni C, Dovero S, Aubert I, Li Q, Bioulac BH, Bloch B, Gurevich EV, Gross CE, Bezard E (2005) Levodopa-induced dyskinesia in MPTPtreated macaques is not dependent on the extent and pattern of nigrostrial lesioning. Eur J Neurosci 22:283-287.

Harrison MB, Wiley RG, Wooten GF (1990) Selective localization of striatal D1 receptors to striatonigral neurons. Brain Res 528:317-322.

Hazrati LN, Parent A (1992) Differential patterns of arborization of striatal and subthalamic fibers in the two pallidal segments in primates. Brain Res 598:311-315.

Henry B, Duty S, Fox SH, Crossman AR, Brotchie JM (2003) Increased striatal pre-proenkephalin B expression is associated with dyskinesia in Parkinson's disease. Exp Neurol 183:458-468.

Herrero MT, Augood SJ, Hirsch EC, Javoy-Agid F, Luquin MR, Agid Y, Obeso JA, Emson PC (1995) Effects of L-dopa on preproenkephalin and preprotachykinin gene expression in the MPTP-treated monkey striatum. Neuroscience 68:1189-1198.

Hersch SM, Ciliax BJ, Gutekunst CA, Rees HD, Heilman CJ, Yung KK, Bolam 
JP, Ince E, Yi H, Levey AI (1995) Electron microscopic analysis of $\mathrm{D}_{1}$ and $\mathrm{D}_{2}$ dopamine receptor proteins in the dorsal striatum and their synaptic relationships with motor corticostriatal afferents. J Neurosci 15: 5222-5237.

Ingham CA, Hood SH, Taggart P, Arbuthnott GW (1998) Plasticity of synapses in the rat neostriatum after unilateral lesion of the nigrostriatal dopaminergic pathway. J Neurosci 18:4732-4743.

Jaber M, Dumartin B, Sagne C, Haycock JW, Roubert C, Giros B, Bloch B, Caron MG (1999) Differential regulation of tyrosine hydroxylase in the basal ganglia of mice lacking the dopamine transporter. Eur J Neurosci 11:3499-3511.

Jolkkonen J, Jenner P, Marsden CD (1995) L-DOPA reverses altered gene expression of substance $\mathrm{P}$ but not enkephalin in the caudate-putamen of common marmosets treated with MPTP. Mol Brain res 32:297-307.

Jones NM, Bergeron M (2004) Hypoxia-induced ischemic tolerance in neonatal rat brain involves enhanced ERK1/2 signaling. J Neurochem $89: 157-167$

Le Moine C, Bloch B (1995) D1 and D2 dopamine receptor gene expression in the rat striatum: sensitive cRNA probes demonstrate prominent segregation of D1 and D2 mRNAs in distinct neuronal populations of the dorsal and ventral striatum. J Comp Neurol 355:418-426.

Levesque M, Parent A (2005) The striatofugal fiber system in primates: a reevaluation of its organization based on single-axon tracing studies. Proc Natl Acad Sci USA 102:11888-11893.

Levey AI, Hersch SM, Rye DB, Sunahara RK, Niznik HB, Kitt CA, Price DL, Maggio R, Brann MR, Ciliax BJ (1993) Localization of D1 and D2 dopamine receptors in brain with subtype-specific antibodies. Proc Natl Acad Sci USA 90:8861-8865.

Martin RF, Bowden DM (1996) A stereotaxic template atlas of the macaque brain for digital imaging and quantitative neuroanatomy. NeuroImage 4:119-150

Mengual E, Pickel VM (2002) Ultrastructural immunocytochemical localization of the dopamine D2 receptor and tyrosine hydroxylase in the rat ventral pallidum. Synapse 43:151-162.

Morissette M, Goulet M, Soghomonian J-J, Blanchet PJ, Calon F, Bédart PJ, Paolo TD (1997) Preproenkephalin mRNA expression in the caudateputamen of MPTP monkeys after chronic treatment with the $\mathrm{D}_{2}$ agonist U91356A in continuous or intermittent mode of administration: comparison with L-dopa therapy. Mol Brain Res 49:55-62.

Morissette M, Grondin R, Goulet M, Bedard PJ, Di Paolo T (1999) Differential regulation of striatal preproenkephalin and preprotachykinin mRNA levels in MPTP-lesioned monkeys chronically treated with dopamine D-1 or D-2 receptor agonists. J Neurochem 72:682-692.

Moritoyo T, Izumo S, Moritoyo H, Tanaka Y, Kiyomatsu Y, Nagai M, Usuku K, Sorimachi M, Osame M (1999) Detection of human T-lymphotropic virus type I p40tax protein in cerebrospinal fluid cells from patients with human T-lymphotropic virus type I-associated myelopathy/tropical spastic paraparesis. J Neurovirol 5:241-248.

Mushiake H, Inase M, Tanji J (1991) Neuronal activity in the primate premotor, supplementary, and precentral motor cortex during visually guided and internally determined sequential movements. J Neurophysiol 66:705-718

Nadjar A, Combe C, Busquet P, Dantzer R, Parnet P (2005) Signaling pathways of interleukin-1 actions in the brain: anatomical distribution of phospho-ERK1/2 in the brain of rat treated systemically with interleukin1beta. Neuroscience 134:921-932.
Ohno Y, Sasa M, Takaori S (1987) Coexistence of inhibitory dopamine D-1 and excitatory D-2 receptors on the same caudate nucleus neurons. Life Sci 40:1937-1945.

Parent A, Hazrati LN (1994) Multiple striatal representation in primate substantia nigra. J Comp Neurol 344:305-320.

Parent A, Hazrati LN (1995) Functional anatomy of the basal ganglia. I. The cortico-basal ganglia-thalamo-cortical loop. Brain Res Brain Res Rev 20:91-127.

Parent A, Bouchard C, Smith Y (1984) The striatopallidal and striatonigral projections: two distinct fiber systems in primate. Brain Res 303:385-390.

Parent A, Smith Y, Filion M, Dumas J (1989) Distinct afferents to internal and external pallidal segments in the squirrel monkey. Neurosci Lett 96:140-144.

Parent A, Charara A, Pinault D (1995) Single striatofugal axons arborizing in both pallidal segments and in the substantia nigra in primates. Brain Res 698:280-284.

Penny GR, Afsharpour S, Kitai ST (1986) The glutamate decarboxylase-, leucine enkephalin-, methionine enkephalin- and substance P-immunoreactive neurons in the neostriatum of the rat and cat: evidence for partial population overlap. Neuroscience 17:1011-1045.

Qvigstad G, Qvigstad T, Westre B, Sandvik AK, Brenna E, Waldum HL (2002) Neuroendocrine differentiation in gastric adenocarcinomas associated with severe hypergastrinemia and/or pernicious anemia. Apmis 110:132-139.

Selemon LD, Goldman-Rakic PS (1990) Topographic intermingling of striatonigral and striatopallidal neurons in the rhesus monkey. J Comp Neurol 297:359-376.

Seppanen O, Glumoff V, Paananen R, Rounioja S, Hallman M (2005) Transcription factors NF-kappaB and C/EBPdelta and IL-1-induced expression of surfactant protein A in lung explants during the perinatal period. Biol Neonate 87:152-159.

Stephens B, Mueller AJ, Shering AF, Hood SH, Taggart P, Arbuthnott GW, Bell JE, Kilford L, Kingsbury AE, Daniel SE, Ingham CA (2005) Evidence of a breakdown of corticostriatal connections in Parkinson's disease. Neuroscience 132:741-754.

Surmeier DJ, Song W-J, Yan Z (1996) Coordinated expression of dopamine receptors in neostriatal medium spiny neurons. J Neurosci 16:6579-6591.

Tel BC, Zeng BY, Cannizzaro C, Pearce RK, Rose S, Jenner P (2002) Alterations in striatal neuropeptide mRNA produced by repeated administration of L-DOPA, ropinirole or bromocriptine correlate with dyskinesia induction in MPTP-treated common marmosets. Neuroscience 115 1047-1058.

Wang H, Pickel VM (2002) Dopamine D2 receptors are present in prefrontal cortical afferents and their targets in patches of the rat caudateputamen nucleus. J Comp Neurol 442:392-404.

Wang HB, Laverghetta AV, Foehring R, Deng YP, Sun Z, Yamamoto K, Lei WL, Jiao Y, Reiner A (2006) Single-cell RT-PCR, in situ hybridization histochemical, and immunohistochemical studies of substance P and enkephalin co-occurrence in striatal projection neurons in rats. J Chem Neuroanat 31:178-199.

Zachariou V, Sgambato-Faure V, Sasaki T, Svenningsson P, Berton O, Fienberg AA, Nairn AC, Greengard P, Nestler EJ (2006) Phosphorylation of DARPP-32 at threonine-34 is required for cocaine action. Neuropsychopharmacology 31:555-562. 